\title{
The development of brittle structures in an alpine valley glacier: Pasterzenkees, Austria, 1887-1997
}

\author{
Paul HERBST, ${ }^{1}$ Franz NEUBAUER, ${ }^{1}$ Martin P.J. SCHÖPFER ${ }^{2}$ \\ ${ }^{1}$ Division General Geology and Geodynamics, Salzburg University, Hellbrunnerstrasse 34, A-5020 Salzburg, Austria \\ E-mail: paul.herbst@gwu.at \\ ${ }^{2}$ Fault Analysis Group, School of Geological Sciences, University College Dublin, Belfield, Dublin 4, Ireland
}

\begin{abstract}
Brittle structures exposed in the ablation area of Pasterzenkees, Austria, were interpreted using aerial photographs and maps covering a period of 100 years. The most common structural features observed in aerial photographs are: (1) normal faults, which are particularly well developed along the lateral margins of the glacier and at the terminus; (2) large-scale tension gashes and Riedel shears that develop along the northeastern lateral margin of the glacier and between ice-flow units; (3) thrust faults, which develop at the terminus and cross-cut the full width of the glacier; and (4) band ogives. Longitudinal and transverse topographic profiles are available for the period covered in this study, and ice-flow velocity data are available from 1927 . These data provide a means for interpreting the variations of observed structures in terms of ice-flow velocity. Thrust faults predominantly develop during periods of glacier retreat, when the glacier snout becomes an obstacle. Normal faults typically develop in areas of high glacier surface relief and are interpreted as gravity collapse structures. The orientation of sub-vertical, wide open crevasses along the lateral margin of Pasterzenkees varied. These variations are interpreted as reflecting changes of the flow regime and indicate a transition from simple shearing to transtension during a period of ice-flow deceleration.
\end{abstract}

\section{INTRODUCTION}

Glaciers consist of ice, which can be considered as a monomineralic metamorphic rock. The gravity-driven flow of glaciers leads to the formation of both brittle (e.g. crevasses) and ductile (e.g. folds) structures within the ice. Structures that develop both within the glacier and in its associated sediments are in many respects similar to those observed in rocks (e.g. Croot, 1987). A considerable amount of research has been conducted on the flow and structure of arctic (e.g. Hudleston and Hooke, 1980), polythermal (e.g. Hambrey and Milnes, 1977) and surging glaciers (e.g. Sharp and others, 1988; Lawson and others, 1994). However, detailed structural investigations on alpine glaciers are rare (e.g. Hambrey and Milnes, 1977; Hambrey and Lawson, 2000). Faulting within alpine glaciers is an especially poorly studied phenomenon, yet an important deformation mechanism in some regions of a glacier (e.g. Hambrey and others, 1997; Herbst and Neubauer, 2000). Few studies have investigated the long-term variations of glacial structures, mainly due to the lack of reliable observational data. One such study is by Lawson (1996), who described the structural evolution of a temperate surge-type glacier in Alaska. Presently, there is no comprehensive study that focuses on the temporal and spatial evolution of brittle structures that develop within an Alpine glacier over a long ( 100 year) period.

Good observational data are available for Pasterzenkees, Austria (Fig. 1a and b), since 1887 and include accurate maps published by the Austrian Alpine Club since the early 20th century and by the Imperial Geographical Survey of Austria in the 19th century. These maps were compiled for mountaineers and therefore contain details of the distribution and location of crevasses. Additionally, large-scale aerial photographs are commercially available from the Austrian authorities since 1953. Furthermore, detailed structural mapping of the glacier tongue was carried out in
1997/98 by Herbst and Neubauer (2000). This 1997 structural map provides a link between the actual structures and their appearance in aerial photographs.

This study focuses on the relatively flat glacier tongue of Pasterzenkees at elevations below $2500 \mathrm{~m}$ (Fig. 1b). For the time period between $1887 / 89$ and 1928, maps were used to determine the pattern of crevasses and other brittle structures. For the period from the early 1950s to 1997, large-scale vertical aerial photographs were used. The maps were published at a scale of 1:25000 and the aerial photographs are at scales ranging between 1:50000 and $1: 10000$ (Table 1). The topographic changes obtained from these data have been used to model volume changes of Pasterzenkees (Herbst and others, 2002). The aim of this study is to describe the temporal and spatial variations of brittle structures that have developed within Pasterzenkees over a period of 100 years.

\section{GLACIOLOGY OF PASTERZENKEES}

Pasterzenkees, located in the Hohe Tauern National Park in Carinthia, is the largest glacier in Austria. It is approximately $7 \mathrm{~km}$ long, has a maximum width of $5 \mathrm{~km}$ and covers an area of almost $16 \mathrm{~km}^{2}$. It is divided into three distinct areas:

1. a wide accumulation area above $2800 \mathrm{~m}$ (Fig. 1b);

2. a steep $\left(50^{\circ}\right)$, intensely crevassed icefall, Hufeisenbruch. Within the icefall the glacier separates into several iceflow units due to subglacial rock ridges that cause local ice thinning (some of these ridges, which have appeared in the last 20 years, are exposed in the icefall);

3. a typical valley-glacier-type ablation area (study area; Fig. 1b) extending from 2500 to 2100 ma.s.l. (in 1997).

Pasterzenkees has undergone continuous retreat, except for a few short periods of stability (Paschinger, 1969; Patzelt, 1970, 


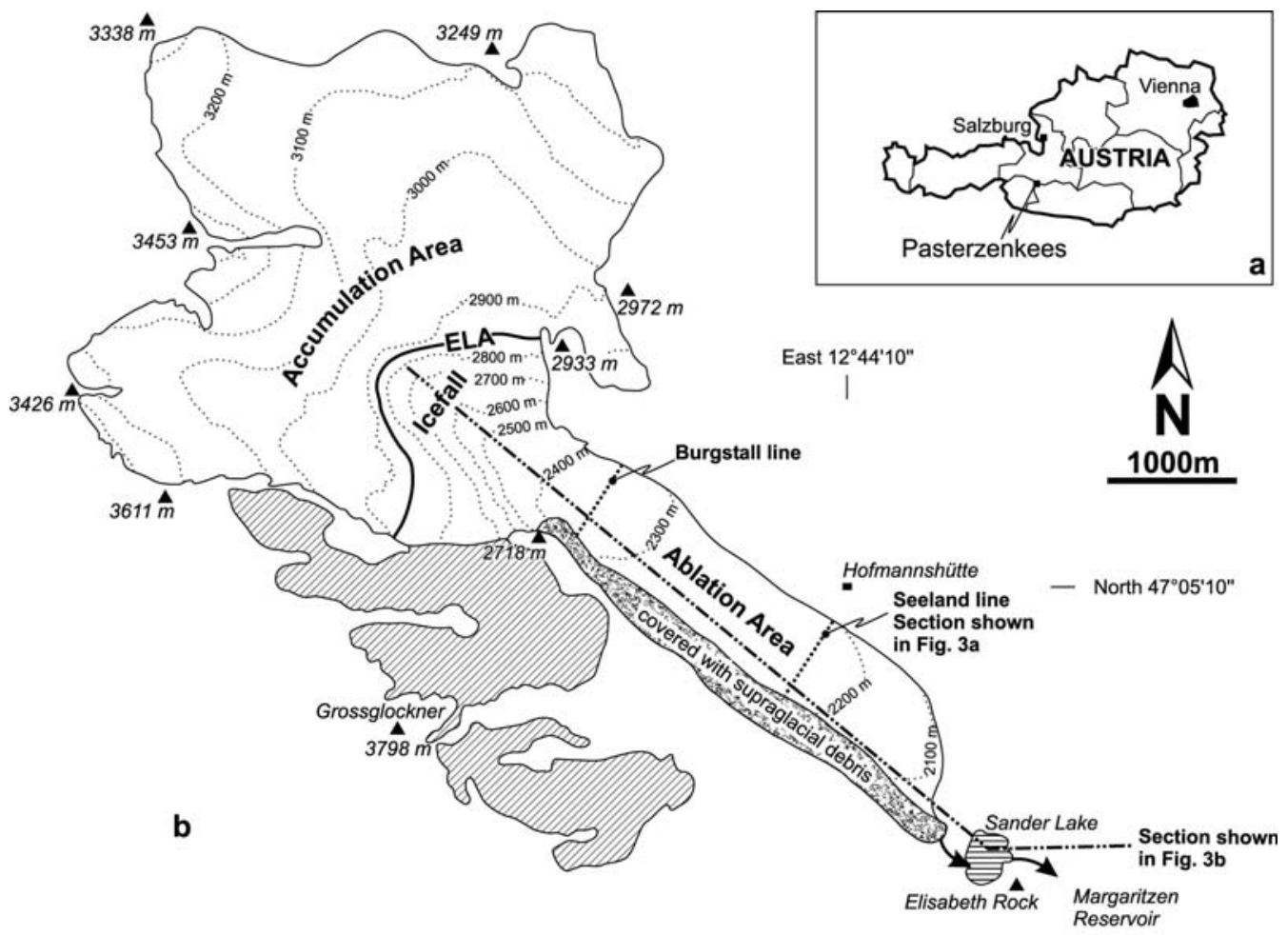

Fig. 1. (a) Location of Pasterzenkees, Austria. (b) Pasterzenkees in $~ 1997$. Equilibrium-line altitude (ELA) is at approximately $2850 \mathrm{~m}$. The locations of profiles and lines of continuous velocity measurements are shown. Numbers given are in metres above sea level. Dashed areas illustrate former tributaries to Pasterzenkees.

1985; Wakonigg and Lieb, 1996), since its last period of advance peaked in the 1850s (end of Little Ice Age or Modern Period of Advance; Patzelt, 1999), when it reached the area of the present-day Margaritzen reservoir (Fig. 1b). Due to its long response time (70-137 years for length and 34-50 years for volume; Zuo and Oerlemans, 1997), Pasterzenkees did not advance during periods of decreased temperature and increased precipitation, in the 1920s and from 1965 to 1980, which caused the majority (75\%) of Austria's smaller glaciers to advance (Patzelt, 1970, 1985). During the period 1965-80, the average ablation-season temperature dropped by $1{ }^{\circ} \mathrm{C}$ and precipitation increased by $3-4 \%$ in high Alpine regions of the Eastern Alps. While, as stated, the majority of Austrian glaciers advanced, Pasterzenkees only exhibited a decrease in annual retreat rate due to its long response time

Table 1. Overview of maps and aerial photographs used in this study

\begin{tabular}{|c|c|c|c|}
\hline $\begin{array}{l}\text { Map } \\
\text { (year) }\end{array}$ & $\begin{array}{c}\text { Aerial photograph } \\
\text { (year) }\end{array}$ & Editor & Scale \\
\hline $1887 / 89$ & & Imperial Authorities & $1: 25000$ \\
\hline \multirow[t]{8}{*}{1928} & & Austrian Alpine Club (ÖAV) & $1: 25000$ \\
\hline & 1953 & $\mathrm{BEV}^{*}$ & $1: 10000$ \\
\hline & 1958 & $\mathrm{BEV}^{*}$ & $1: 10000$ \\
\hline & 1969 & $\mathrm{BEV}^{*}$ & $1: 25000$ \\
\hline & 1978 & $\mathrm{BEV}^{*}$ & $1: 25000$ \\
\hline & 1983 & $\mathrm{BEV}^{*}$ & $1: 50000$ \\
\hline & 1991 & $\mathrm{BEV}^{*}$ & $\sim 1: 30000$ \\
\hline & 1997 & National Park Authority & Digital \\
\hline
\end{tabular}

*Bundesamt für Eich- und Vermessungswesen (Austrian Authorities for Land Survey).
(Paschinger, 1969). Ice-flow velocities were measured almost every year along two transverses over a period of $>70$ years (Wakonigg and Lieb, 1996). Velocities decreased from the time the first measurements were taken in 1927 until 1960. Afterwards the velocity increased continuously, reaching a maximum in the early $1980 \mathrm{~s}$, with values of $>50 \mathrm{~m} \mathrm{a}^{-1}$ in the central part of the ablation area (Seeland line; Fig. 1b) and nearly $80 \mathrm{~m} \mathrm{a}^{-1}$ in the upper ablation area (Burgstall line; Figs $1 \mathrm{~b}$ and 2). Since the 1980s the velocities measured along all standard profiles have decreased by a factor of approximately 0.5 (Fig. 2). Additionally, the glacier thinned

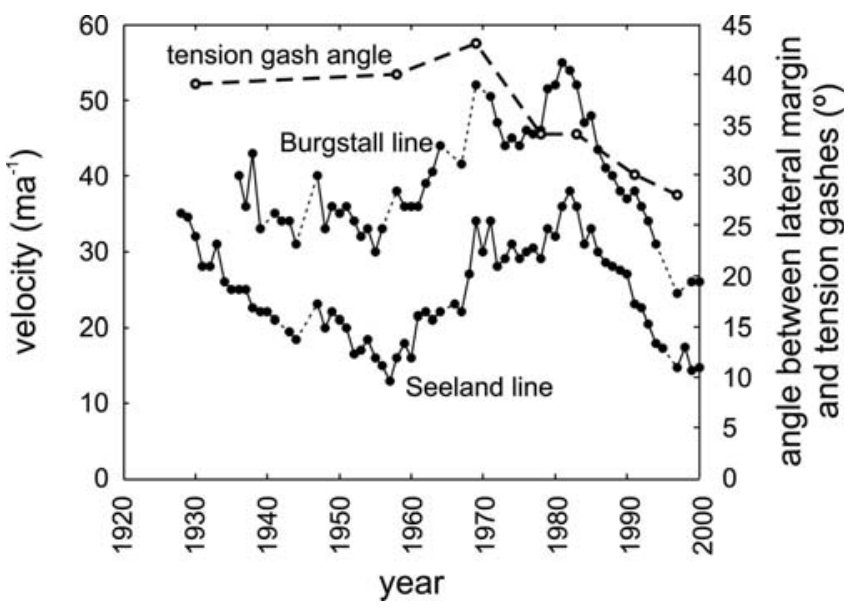

Fig. 2. Ice-flow velocities since 1927 (Seeland line) and 1935 (Burgstall line) measured at two traverses (see Fig. 1b for locations). Dotted lines connect data points where no measurements were taken. The angle between lateral crevasses and the glacier margin is also shown (bold dashed line). 


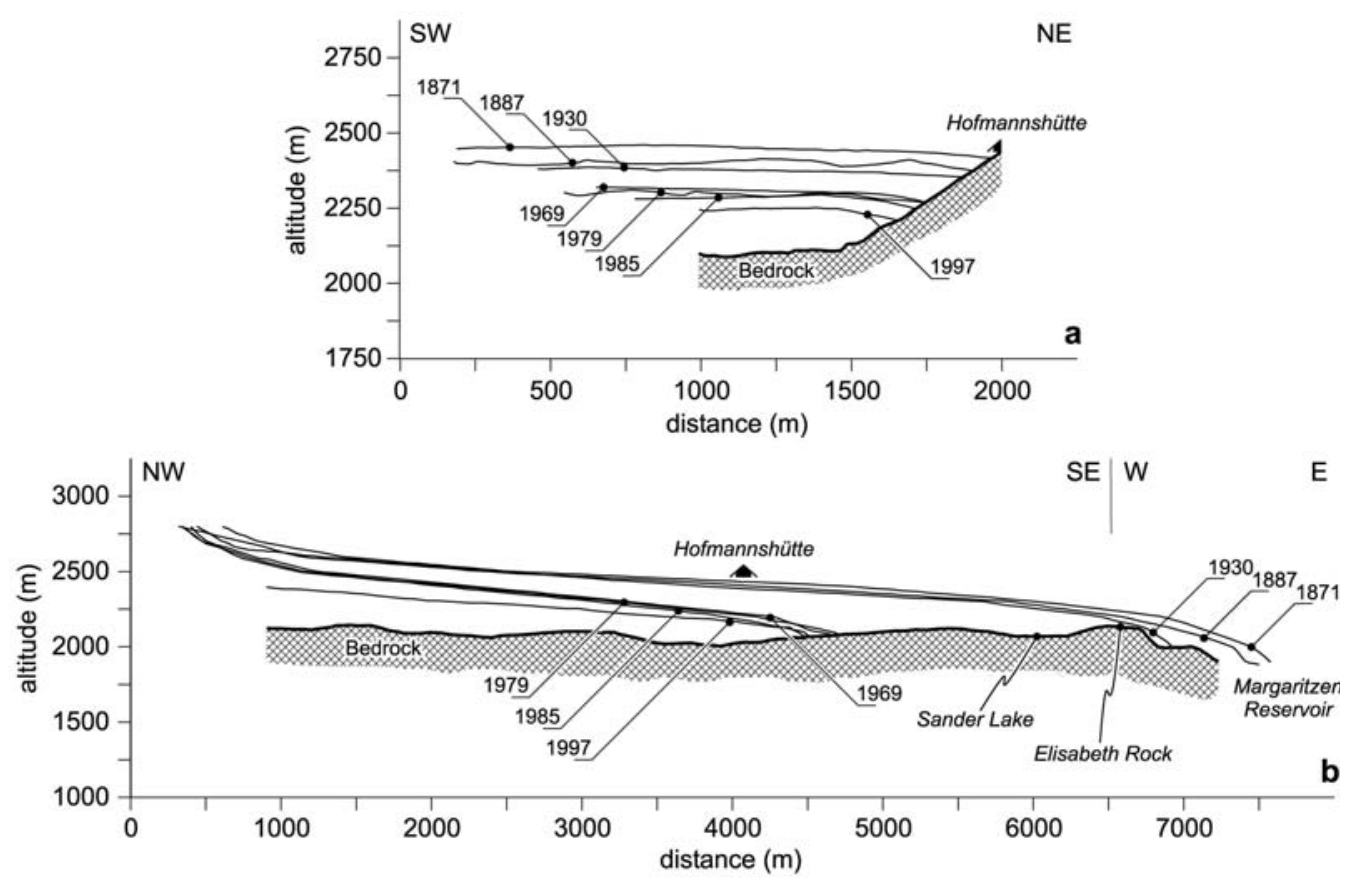

Fig. 3. (a) Cross-section of Pasterzenkees illustrating thickness changes since 1871. (b) Longitudinal sections of glacier illustrating both thickness and length variations. Locations of sections are given in Figure 1b. The bedrock morphology was determined using groundpenetrating radar (GPR; personal communication from N. Span and M. Kuhn, 1998).

dramatically, with an average thickness loss of $2.1 \mathrm{ma}^{-1}$ in the ablation area in the period 1938-94 (Wakonigg and Lieb, 1996). A cross-section of the ablation area located at the Seeland line is shown in Figure $3 a$ and illustrates the dramatic glacier thinning between 1871 and 1997. The morphology of the glacier bed was determined in 1997 using both a ground-penetrating radar (GPR; personal communication from N. Span and M. Kuhn, 1998) and a seismic survey (Fig. 3). The surveys (Fig. 3) revealed an approximately 30-40 m deep depression near the present-day terminus, at a horizontal distance of approximately $4300 \mathrm{~m}$ from the bottom of the icefall. Another, smaller depression is located at a distance of $2200 \mathrm{~m}$.

The following sections describe structural features of the glacier using standard structural geology terminology (e.g. Ramsay and Huber, 1987; Twiss and Moores, 1992). Horizontal extension of the Earth's crust is mainly accompanied by typically $60-70^{\circ}$ dipping shear fractures, called normal faults, although, at low effective stress, brittle materials can fail by pure opening. Horizontal shortening is typically accompanied by relatively shallow-dipping shear fractures, which are called thrust faults if their dip is $<45^{\circ}$ (reverse faults if the dip is $>45^{\circ}$ ). Horizontal relative movement of rock masses or blocks without significant vertical displacement is typically accompanied by subvertical shear fractures, called strike-slip or wrench faults.

Depending on deformation conditions and rheology, faults can be discrete slip-planes or zones of localized, but continuous, deformation (shear zones). Within these shear zones, systematically stepping (en échelon) fracture/fault segments often develop with an initial inclination relative to the shear direction, which depends on material properties and the amount of shear zone perpendicular shortening/ stretching (Naylor and others, 1986; Peacock and Sanderson, 1995). Pure opening fractures within shear zones are called tension gashes, whereas shear fractures are called
Riedel shears. During progressive shearing, existing fracture/ fault segments rotate while new fractures can develop (Ramsay and Huber, 1987). This synchronous rotation of existing fractures and the formation of new tension gashes/ Riedel shears can lead to complex fracture patterns, where younger fractures offset and cross-cut earlier structures.

\section{The accumulation area and icefall}

The accumulation area, which is not the primary study area in this paper, is situated within a wide, flat region where two large valleys, which reach elevations of $\sim 3400$ m a.s.l., join. The ice-flow units of these valleys are separated by a topographic ridge (Fig. 1b). The ice masses flow from the accumulation area over the steep icefall to the much shallower ablation area. Within the icefall, which is characterized by intense and typically irregular crevassing, rock ridges are exposed. These rock ridges divide the glacier into three units that flow into the relatively flat region of the ablation area.

\section{The ablation area: recent structural geology}

The glacier within the ablation area is comprised of three distinct flow units: the northeastern, central and southwestern (Fig. 4b). At the surface the three flow units are easily distinguished by supraglacial debris. Each of these units exhibits a penetrative foliation with a typical spoonlike orientation (first described by Schwarzacher and Untersteiner, 1953; see also Herbst and Neubauer, 2000). The ice masses in between the flow units are intensely sheared and exhibit shear folds with an axial planar foliation (Hambrey and Glasser, 2003).

Although the flow units can be distinguished easily using surface and structural (e.g. foliation) observations, no complete transverse velocity measurements are yet available that can demonstrate that each unit has its own (map-view parabolic?) velocity distribution. 

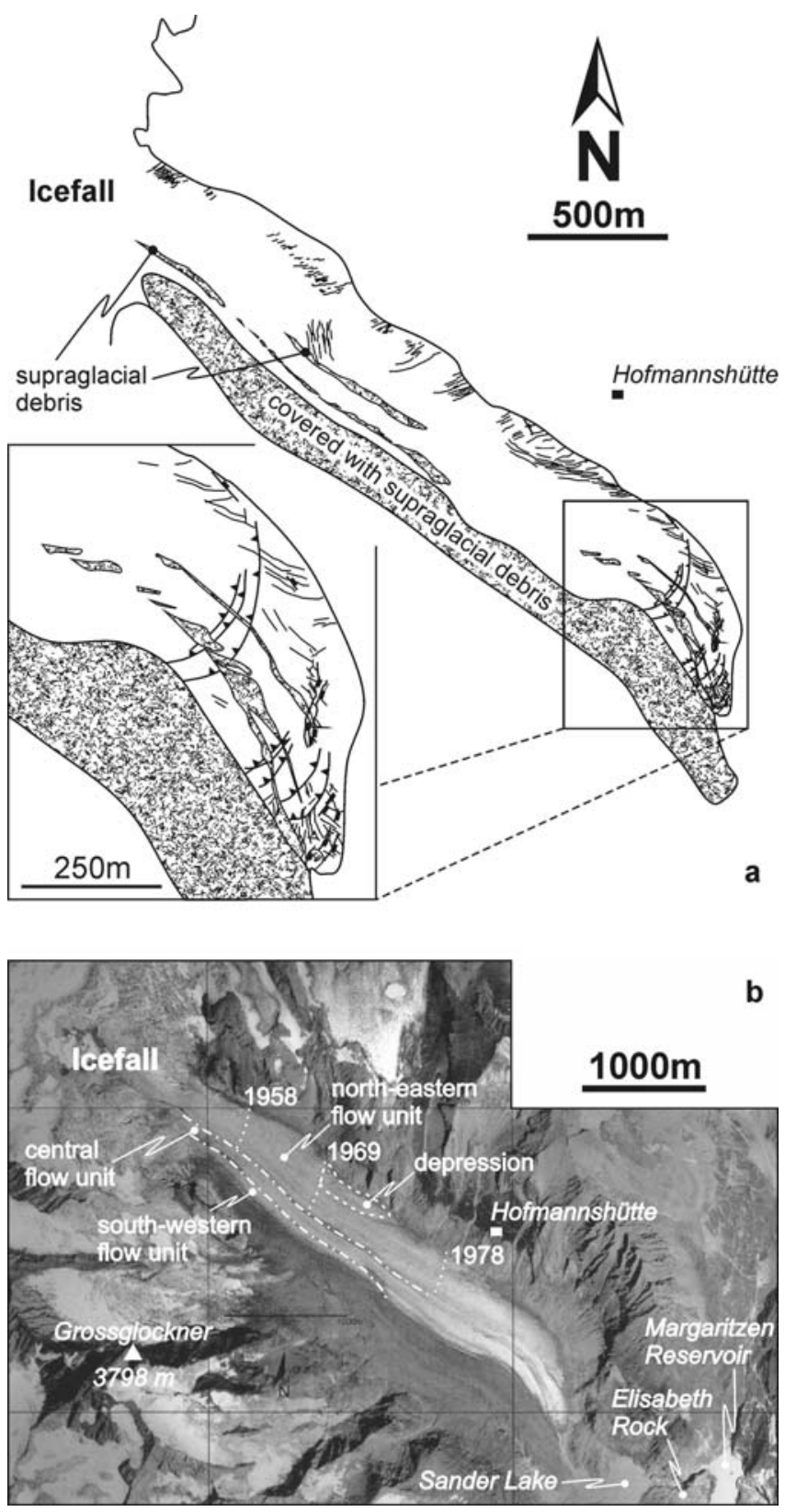

Fig. 4. (a) Map based on aerial photographs and fieldwork, illustrating brittle structures within Pasterzenkees in 1997. Supraglacial till (dotted areas) indicates the presence of three flow units. Solid lines with triangles are traces of thrust faults (triangles point towards hanging wall, i.e. up-thrown side). Solid lines are tension gashes and crevasses of unknown origin. Solid lines with rectangles are traces of normal faults (rectangles point towards hanging wall, i.e. downthrown side). Inset shows a $\times 2$ enlargement of the snout (rectangle). (b) 1997 aerial photograph of Pasterzenkees illustrating the presence of three flow units. Location of glacier surface depression is shown. The lower limits of band ogives since 1958 are shown as dashed lines.

Detailed structural mapping (1997/98) revealed that five structural domains can be distinguished (from icefall to terminus):

1. A contractional region in the uppermost part of the ablation area just below the icefall that exhibits structures similar to those described in Ragan (1969) as mushroom folds and thrust faults.

2. An area characterized by large-scale tension gashes on the northeastern margin of the glacier.

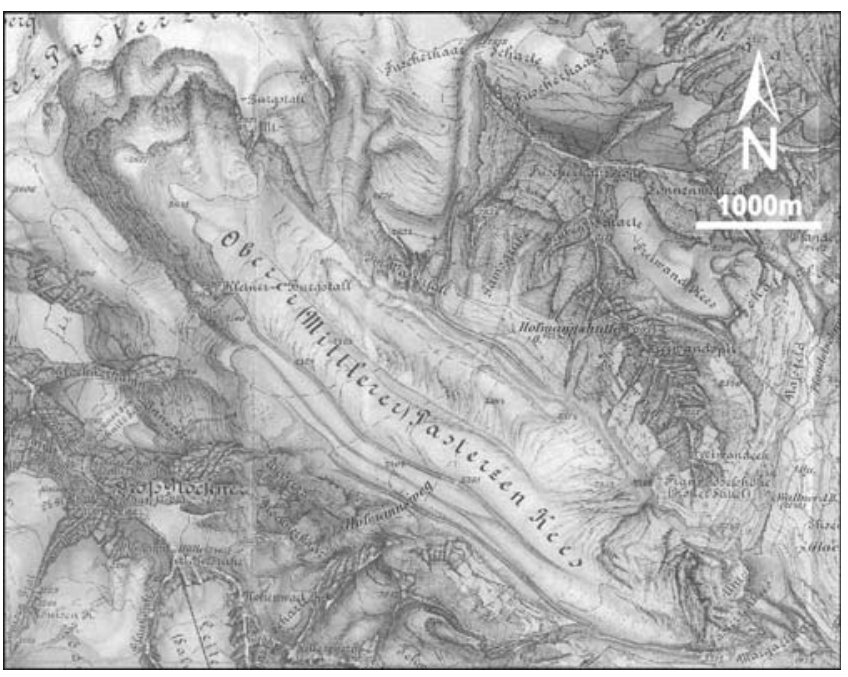

Fig. 5. Imperial Geographical Survey of Austria map from 1887/89.

3. An area of extension that exhibits a large number of pure opening fractures that develop sub-perpendicular to the flow direction.

4. A predominantly contractional region with large arcuate, downslope convex thrust faults that cut the entire glacier.

5. An area of extension at the terminus with large normal faults, where the down-thrown blocks become dead ice.

Band ogives, which develop below the icefall, are exposed only within the northeastern flow unit and can be mapped for approximately $2.4 \mathrm{~km}$ downslope. In the following section the spatial and temporal variations of the structures described above are given in detail.

\section{OBSERVATIONS: STRUCTURAL EVOLUTION OF THE GLACIER SINCE 1887/89}

\section{7/89}

Pasterzenkees exhibits a morphology that is typical for glaciers during periods of advance/steady state (Figs 5 and $6 \mathrm{a}$ ). The ablation area covers $8.6 \mathrm{~km}^{2}$, and the horizontal distance between icefall and terminus is $7500 \mathrm{~m}$ (Fig. 3b). The terminus is at an elevation of approximately $1920 \mathrm{~m}$, with a horizontal distance to the terminal position in 1997 of $\sim 3 \mathrm{~km}$. The crevasse pattern indicates that the glacier is comprised of two flow units. The area between these units is characterized by relatively small en échelon crevasses (area 2 in Fig. 6a) and further downslope by large, sigmoidal crevasses (area 1 in Fig. 6a). These features indicate a rightlateral sense of shear. In the northeastern part of the glacier, arcuate crevasses with downslope-pointing lateral tips are interpreted as normal faults that formed in the vicinity of a glacier surface depression (area 3 in Fig. 6a). Rotated tension gashes in the northwestern part of the glacier (area 4 in Fig. 6a) are interpreted as the first signs of the separation of the central and southwestern ice flow. The concave downslope fractures below the icefall are interpreted as normal faults. The glacier snout is an intensely crevassed icefall.

\section{8}

In 1928, Pasterzenkees is smaller than in 1887 and is in retreat, except for a few years of advance between 1910 and 


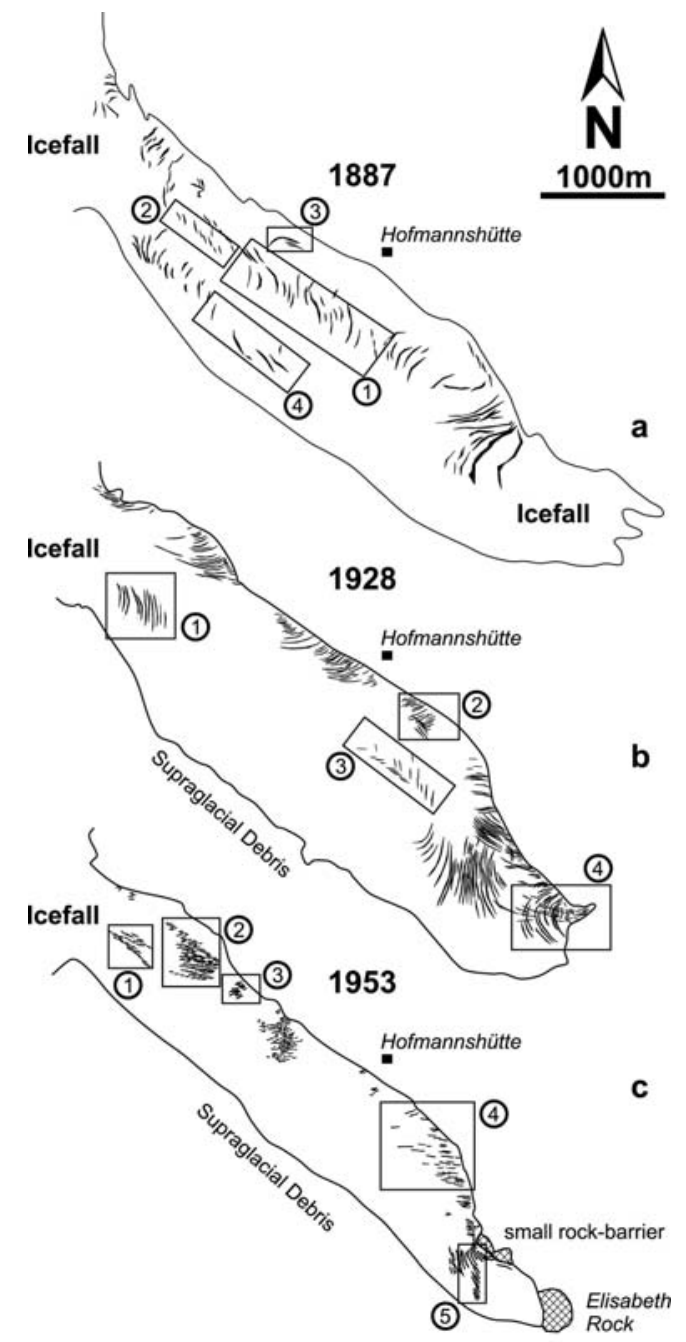

Fig. 6. Structural interpretations: (a) 1887/89: 1. left-stepping sigmoidal crevasses; 2 . crevasses exhibiting en échelon (leftstepping) geometry; 3 . depression with arcuate normal faults; 4. rotated tension gashes. (b) 1928: 1. normal faults; 2 . tension gashes cross-cut by normal faults oriented parallel to the lateral margin; 3. complicated array of crevasses exhibiting en échelon geometry with both right- and left-stepping segments; 4. large-scale concave downslope normal faults and small-scale convex downslope thrusts. (c) 1953: 1. en échelon arranged crevasses oriented sub-parallel to flow direction; 2 . large crevasse field; 3 . depression with normal faults; 4 . crevasses (tension gashes) oriented $\sim 45^{\circ}$ relative to the flow direction; 5. en échelon crevasses due to rock barrier.

1935 (Wakonigg and Lieb, 1996). Ice-flow velocity data are available for the first time (Seeland line; Fig. 2) and indicate that this part of the glacier is moving at a velocity of $35 \mathrm{~m} \mathrm{a}^{-1}$. The terminus is at an elevation of $\sim 2030 \mathrm{~m}$, and the distance between terminus and icefall is $6900 \mathrm{~m}$ (Fig. 3b). The southwestern flow unit is covered by supraglacial debris over wide areas, and the total ablation area is $7.6 \mathrm{~km}^{2}$. A field of large, left-stepping tension gashes is exposed in the northwestern sector close to the icefall (area 1 in Fig. 6b). The majority of crevasses, which have developed since 1887, are distributed along the lateral (northeastern) margin of the glacier (Fig. 6b) and typically exhibit right-stepping en échelon geometry. In one particular area (area 2 in Fig. 6b), normal faults oriented parallel to the margin cut these crevasses. A zone of en échelon crevasses in the central part of the glacier suggests two flow units (area 3 in Fig. 6b). This interpretation is supported by the contour pattern in the 1928 map, which indicates the presence of two distinct ice ridges parallel to the glacier's lateral margins. Large normal faults have developed in the terminal area (up-slope from area 4 in Fig. 6b) due to an underlying bedrock step. The snout is an intensely crevassed icefall and contains large concave downslope normal faults and small convex downslope thrusts (area 4 in Fig. 6b).

\section{3}

In 1953 the glacier is smaller than before, and a topographic high of the bedrock, the Elisabeth rock, appears (Fig. 6c). Ice-flow velocity at the Seeland line has decreased steadily since the first measurements were taken (1927) and is $18 \mathrm{~m} \mathrm{a}^{-1}$ (Fig. 2). The majority of crevasses are located in the northeastern part of the glacier. Close to the base of the icefall, a zone of right-stepping en échelon crevasses appears (area 1 in Fig. 6c). This region is interpreted as a left-lateral shear zone that divides the central and northeastern flow units. Additionally, two large fields of rightstepping en échelon crevasses have developed (area 2 and $750 \mathrm{~m}$ southeast of area 2 in Fig. 6c). These areas are interpreted as wide left-lateral shear zones that reflect the fact that the ice flows faster in the centre than at the margin. Normal faults have developed in the vicinity of a glacial depression (area 3 in Fig. 6c). Another field of crevasses that are interpreted as tension gashes is exposed south-southeast of the Hofmannshütte (area 4 in Fig. 6c). The structure of the terminal region is significantly different than before. The snout is relatively shallow-dipping and rich in debris, which is typical for retreating glaciers. A small topographic high of bedrock, which has a significant impact on the crevasse pattern, appears at the northern margin of the terminal area (area 5 in Fig. 6c). Large crevasses are concave towards this rock barrier and are interpreted as normal faults. Additionally, a north-south-trending shear zone of right-stepping en échelon crevasses has developed, probably due to the bend which causes a decrease in the glacier's crosssectional area.

The 1953 and later interpretations are based on aerial photographs, so the distribution of band ogives can be described. In 1953 they are only exposed in the uppermost part of the ablation area at the bottom of the icefall.

\section{8}

During the period 1953-58 the glacier retreated rapidly, with a maximum rate of $20 \mathrm{~m} \mathrm{a}^{-1}$ (Wakonigg and Lieb, 1996). Iceflow velocity at the Seeland line is $16 \mathrm{~m} \mathrm{a}^{-1}$, its lowest since the first measurements were taken (1927). The Elisabeth rock is fully exposed and the previously described rock barrier (Fig. 6c) does not have a significant impact on the crevasse pattern within the terminal region (Fig. 7a). In contrast to the previous stage, right-stepping en échelon crevasses are exposed along the entire length of the northeastern margin. Band ogives are only visible in the uppermost part of the ablation area at the bottom of the icefall (Fig. 4b).

\section{9}

During the period 1960-80 the average temperature during the ablation season decreased by $1{ }^{\circ} \mathrm{C}$ and precipitation increased by $3-4 \%$ in high Alpine regions of the Eastern Alps (Patzelt, 1970, 1985). This caused a decrease in the annual retreat rate of Pasterzenkees (Paschinger, 1969) and an 
increase in ice-flow velocity (Fig. 2). The horizontal distance between icefall and terminus is $4600 \mathrm{~m}$, and the debris-free part of the ablation area covers $5.04 \mathrm{~km}^{2}$. Since 1958, iceflow velocity at the Seeland line has increased to $34 \mathrm{~m} \mathrm{a}^{-1}$. The area of en échelon crevasses located approximately $1 \mathrm{~km}$ downslope from the icefall (area 1 in Fig. 7b) covers the entire width of the northeastern ice flow. Normal faults are exposed in the vicinity of the previously described glacial depression (area 2 in Fig. 7b). A new structural feature at the 1969 stage is the development of wide-open crevasses that are oriented parallel to the bulk flow direction in the central part of the glacier, southwest of the Hofmannshütte (area 3 in Fig. 7b). These are interpreted as normal faults that formed due to the steep gradient of relief that developed between the debris-covered southwestern part of the glacier and its debris-free northeastern part. Another new structural feature is cross-cutting of crevasses at the lateral margin of the glacier (area 4 in Fig. 7b). The crevasses that are oriented sub-perpendicular to the glacier margin are interpreted as representing an older set of fractures that was rotated anticlockwise during progressive left-lateral shearing. These rotated crevasses were then crosscut by a new generation of tension gashes oriented at approximately $45^{\circ}$ to the glacier margin, a feature that is also typical for brittle/ductile shear zones in rock (e.g. Ramsay and Huber, 1987). In the terminal area of the glacier, the trace of a small thrust fault is visible (area 5 in Fig. 7b), a structure which becomes more pronounced at later stages (see below). Band ogives are exposed within the northeastern flow unit in an area extending from the base of the icefall to the bedrock depression (area 2 in Fig. 7b). Since 1958 the lower limit of band ogives has migrated approximately $620 \mathrm{~m}$ (Fig. 4b).

\section{8}

The crevasse density appears to have increased significantly in the period 1969-78, especially along the northeastern margin of the glacier (Fig. 7c). The velocity at the Seeland line is $29 \mathrm{~m} \mathrm{a}^{-1}$. Two distinct zones of en échelon crevasses in the upper part of the ablation area are interpreted as bounding a narrow, central ice flow (area 1 in Fig. 7c; see also Fig. 4b). In the terminal area, arcuate thrust faults, which transport basal till to the glacier surface, cut almost the entire width of the glacier (area 3 in Fig. 7c). Band ogives are visible from the base of the icefall to the Seeland line. Their lateral limit has thus migrated a distance of approximately $1010 \mathrm{~m}$ since 1969 (Fig. 4b).

\section{3}

In the early 1980s, Pasterzenkees flows at its maximum velocity since 1927, when the first measurements were taken (38 and $54 \mathrm{ma}^{-1}$ at the Seeland and Burgstall lines, respectively; Fig. 2). Crevasses are typically wider and longer than at the previous stage. The lengthening of crevasses is supported by the sigmoidal geometry of the lateral en échelon tension gashes (area 2 in Fig. 8a). The sigmoidal geometry of the crevasses can be explained by synchronous anticlockwise rotation and fracture lengthening, a feature that is also common in brittle/ductile shear zones in rocks (Ramsay and Huber, 1987). In the upper part of the ablation area (e.g. area 1 in Fig. 8a), less pronounced sigmoidal crevasses that are oriented sub-perpendicular to the glacier margin are exposed. These are interpreted as rotated tension gashes that ceased to lengthen during

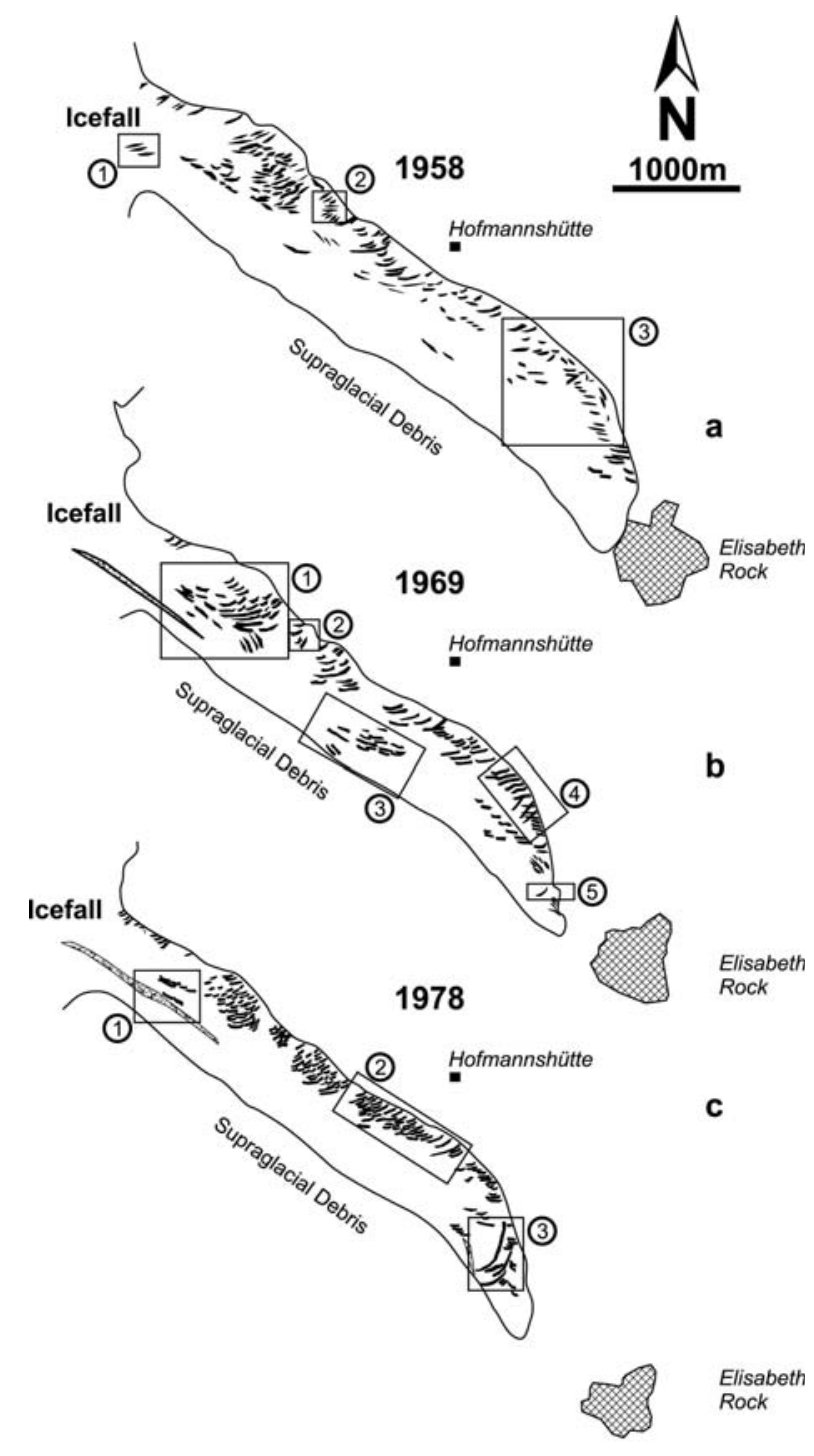

Fig. 7. Structural interpretations: (a) 1958: 1 . crevasses in the upper central part of the glacier; 2 . depression with normal faults; 3 . field of tension gashes. (b) 1969: 1. large crevasse field that extends from the margin to the centre of the glacier; 2 . depression with normal faults; 3 . wide-open crevasses oriented parallel to the bulk flow direction; 4. two generations of tension gashes; 5 . small-scale thrust fault. Light grey areas represent supraglacial debris. (c) 1978: 1. two shear zones that bound the small central flow unit; 2 . field of tension gashes; 3. multiple large thrust faults. Dotted areas represent supraglacial debris.

progressive shearing. Close to the area of the previously described glacier depression, a new set of crevasses, which are interpreted as normal faults, developed. The terminal area is cross-cut by a few normal faults that are interpreted as collapse structures (area 3 in Fig. 8a). A striking feature is the complete absence of thrust faults in the terminal area. The downslope limit of band ogives has not migrated significantly since 1978 and is stationary at this distance at the later stages described below.

\section{1}

Since 1983 the ice-flow velocity has decreased significantly (23 $\mathrm{m} \mathrm{a}^{-1}$; Fig. 2). The new set of normal faults that appeared at the previous stage to the west of the depression (area 1 in Fig. 8b) has become wider and longer. The northeastern ice 


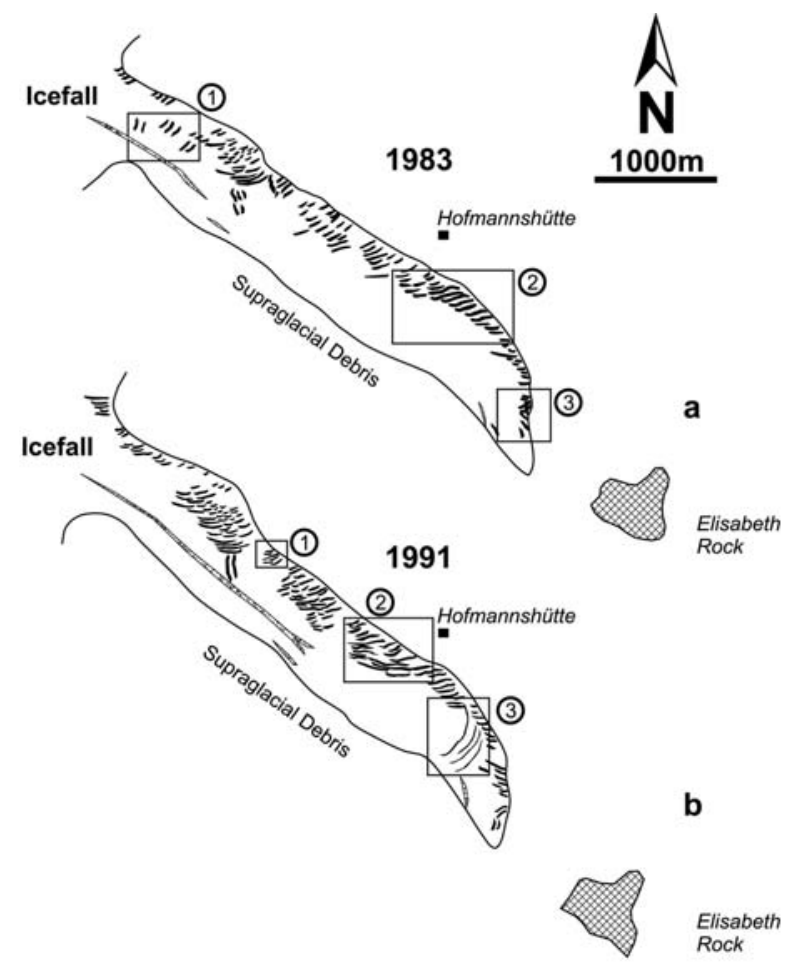

Fig. 8. Structural interpretations: (a) 1983: 1. rotated sigmoidal faults that became perpendicular to flow direction; 2. sigmoidal tension gashes; 3. normal faults. (b) 1991: 1. depression with normal faults; 2. large sigmoidal tension gashes; 3 . thrust faults. Dotted areas represent supraglacial debris.

flow is intensely fractured, and some crevasses have lengthened by a process best described as segment linkage (area 2 in Fig. 8b). In contrast to the previous stage, the lower part of the glacier is cross-cut by long, convex downslope thrust faults. The area of reverse faulting and thus horizontal contraction is further up-slope than in 1978. In the terminal region a few new concave downslope normal faults have developed.

\section{7}

In 1997 the horizontal distance between icefall and terminus is $4500 \mathrm{~m}$, and the longitudinal section reveals that the glacier surface has a gentler slope than at previous stages (Fig. 3b). The debris-free part of the ablation area covers $5.05 \mathrm{~km}^{2}$. The ice-flow velocity has decreased significantly to $15 \mathrm{~m} \mathrm{a}^{-1}$ (Fig. 2). A detailed description of this stage can be found in Herbst and Neubauer (2000); this subsection therefore only describes the predominant brittle structures (Fig. 4a). The upper crevasse field $\sim 1 \mathrm{~km}$ southeast of the icefall, and the crevasse field located southwest of the Hofmannshütte are both narrower than at previous stages. In the Hofmannshütte area the angle between the crevasses and the glacier margin is often much smaller $\left(\sim 25^{\circ}\right)$ than at earlier stages (e.g. $\sim 40^{\circ}$ in 1991). Normal faults in the vicinity of the depression are slightly longer and more numerous than in 1991. The area of thrust faulting in the terminal area is at a position similar to 1991, though some traces of thrust faults are exposed close to the terminus. Some of the thrusts close to the terminus are interpreted as inactive faults of earlier stages, possibly 1991, that migrated passively downslope. This interpretation is supported by the presence of numerous active normal faults that indicate extension of the snout. Thrusting requires horizontal shortening, which cannot be synchronous with stretching in the same direction within the same region of the glacier. The possibility of activity of these thrusts during the winter season, however, cannot be ruled out.

\section{DISCUSSION}

The morphology of the ablation area of Pasterzenkees varied significantly during the last century. In the late 19th century the glacier snout exhibited a relatively high surface gradient in longitudinal section (Fig. 3b). During retreat the slope of the snout became significantly gentler, which is typical for glaciers with a negative mass balance. Additionally, Figure $3 b$ reveals that in the period 1985-97 the glacier terminus retreat rate decreased, though its longitudinal profile changed due to a dramatic decrease in ice thickness. The cross-sectional profile changed from almost flat-topped to convex-up, especially along the northeastern margin (Fig. 3a). These dramatic morphological variations and volume changes clearly demonstrate that Pasterzenkees has been in non-steady state for at least 100 years (Zuo and Oerlemans, 1997). The variability of the origin and distribution of brittle structures exposed in Pasterzenkees described in this paper is interpreted as reflecting variations in ice-flow velocity and therefore mass balance. In this section, the possible origin and distribution of various brittle structures and band ogives over the last century are discussed, though the reader should keep in mind that pre1997 stages are based on map and aerial photograph interpretations.

\section{Normal faults}

Normal faults that develop due to horizontal extension were observed at all stages. Normal faulting within the ice is typically associated with areas of high relief of the glacier's surface. Normal faulting often characterizes the very end of the terminal area, where it is predominantly triggered by ice collapse above subglacial cavities, especially since 1983. Down-thrown blocks become dead ice and are up to $50 \mathrm{~m}^{2}$ in area. In earlier periods (1887-1930), normal faulting in the terminal area was due to the presence of an icefall at the glacier terminus. A common characteristic of normal faults is that they generally dip downslope and that their trace is concave downslope. Exceptions are normal faults that are oriented sub-parallel to the bulk flow direction. These developed in the lateral glacier surface depression and near the boundary between debris-covered and debris-free areas. The origin of the lateral depression is unknown, and GPR measurements did not reveal a depression in the bedrock at this locality. Nevertheless, it appears that this 10-15 m deep depression (depth measured in 1997) caused normal faulting in its vicinity and that it has existed at least since 1953.

\section{Sub-vertical tension gashes}

Sub-vertical crevasses that typically exhibit systematic stepping (en échelon geometry) are the most common brittle structure exposed in Pasterzenkees. These fractures nucleate within shear zones that develop between two flow units or at the lateral margin of the glacier. The direction of stepping is an indicator of the shear sense (e.g. right-stepping segments develop within left-lateral shear zones). Additionally, these en échelon crevasses, which are up to 3-4 m wide, often 
exhibit a sigmoidal shape (cf. Hambrey and Lawson, 2000) which indicates contemporaneous crevasse growth and shearing.

In map view, en échelon crevasses in the upper central part of the ablation area of the glacier are good indicators for the presence of two or more flow units. Further downslope these en échelon crevasses disappear, which could suggest merging of the flow units. The orientation of crevasses within the northeastern lateral margin has varied during the last century (Figs 2 and 6-8). In the first half of the 20th century the angle between the crevasses and the glacier margin was approximately $40^{\circ}$. Since 1969 , when the maximum inclination angle was observed $\left(43^{\circ}\right)$, the inclination decreased to about $28^{\circ}$ in 1997 (Fig. 2). If we assume that crevasses open perpendicular to the lines of instantaneous maximum stretching, then $45^{\circ}$ inclinations are expected under simple shear conditions, i.e. shearing without shortening/stretching perpendicular to the shear zone boundaries. Contemporaneous shearing and extension perpendicular to the shear zone boundaries (transtension), however, leads to inclinations of $<45^{\circ}$ (e.g. Peacock and Sanderson, 1995). The angle variations (Figs 2 and 6-8) thus suggest a transition from (almost perfect) simple shearing to transtension. It appears therefore that the flow regime along the lateral margin varied, though a clear relationship between crevasse inclination and mass balance has not yet been established.

\section{Thrust faults}

Thrust faults that are the result of horizontal shortening develop in the terminal region of Pasterzenkees and exhibit an arcuate, convex downslope trace in map view. Thrusts always dip up-slope and have dips of around $25^{\circ}$, though sometimes steep to over-steepened thrusts are exposed (Herbst and Neubauer, 2000). The arcuate shape of thrust traces in map view could be due to cut effects, i.e. a perfectly planar fault appears curved due to the convex-up cross-sectional profile of the glacier. Structural mapping of active thrusts in 1997 revealed that thrust planes exhibit systematic strike variations and are therefore spoon-shaped (Herbst and Neubauer, 2000). The curvature of these thrusts, however, could be enhanced since the glacier exhibits its greatest velocity in the centre. Thrusts mapped in 1997 transported basal till to the glacier surface; therefore these structures cross-cut the entire glacier and are linked to a basal detachment (see also Hambrey and others, 1997).

Thrust faults are visible in aerial photographs in 1969, 1978 and since 1991. Interestingly no large-scale thrusts developed in 1983, when Pasterzenkees was flowing at its peak velocity since first measurements (1927; Fig. 2). In the second half of the 20th century the first signs of thrust faulting were visible at approximately $100 \mathrm{~m}$ from the terminus (Fig. 7b). It appears that in the following years the area of thrusting increased and migrated up-slope (Fig. 7c). As stated above, no thrusts were exposed in 1983. In 1991, however, a new area of thrust faults was visible at almost $1000 \mathrm{~m}$ from the terminus (Fig. 8b). Especially in 1997, the terminal region of the glacier was cross-cut by many thrusts (Fig. 4a), where the thrusts close to the terminus might be inactive thrusts that migrated downslope. We argue therefore that thrusting is an important deformation mechanism during periods of negative mass balance, probably when the glacier snout becomes an obstacle. Thrusting in glaciers, however, is a poorly understood phenomenon and clearly demands further research.

\section{Band ogives}

Band ogives are characterized by a rhythmic change of dark and light layers of ice, where the dark bands are debris-rich and intensely foliated (Goodsell and others, 2002). In Pasterzenkees, band ogives developed in the northeastern flow unit, but, for reasons yet unknown, were not observed in the central and southwestern flow units (Fig. 4b). The limit of band ogives migrated from the icefall downwards in the period 1958-78. Since 1978 the lower limit of band ogives appears to be stationary at a horizontal distance of approximately $2.4 \mathrm{~km}$ from the icefall; the cause for the apparent stagnation of band ogives is as yet unexplained. The average velocity of the downward migration of the limit of band ogives was 56 and $112 \mathrm{ma}^{-1}$ for the periods 1958-69 and 1969-78, respectively. This suggests a two-fold velocity increase, which is consistent with the measured velocity increase along the two profiles (Fig. 2), though the absolute values of velocity differ.

\section{Comparison with geological structures}

Pasterzenkees exhibits many structural features that are similar to those seen in rocks, both at a small and at a large scale. Since the flow of ice is due to gravity, the deformation of glaciers may serve as an analogue for gravity-driven geological structures. In particular, landslides show remarkably similar fracture patterns, such as large open cracks in the rear, buckling/thrusting at the toe, and shearing with en échelon tension gashes at the lateral margin (e.g. Martel, 2004). On a larger scale, similar structures can be observed at passive continental margins, where kilometres thick delta sequences slide due to gravity above weak rocks (e.g. Mandl and Crans, 1981; Mauduit and others, 1997). Additionally, gravitational collapse structures above low-angle detachments are comparable to structures seen in glaciers (e.g. Rouby and others, 1996). Recently, Herbst and Neubauer (2000) compared some of the structures observed in Pasterzenkees to extensional allochthons within collisional mountain ranges. Finally, the lateral glacial shear zones exhibit tension gash geometries that are remarkably similar to structures formed in brittle/ductile shear zones in rocks (Ramsay and Huber, 1987).

\section{CONCLUSIONS}

Brittle structures that have developed in the last century within Pasterzenkees have been interpreted using maps and aerial photographs. The main conclusions, which might be applied to other temperate Alpine valley glaciers, are:

The development and distribution of brittle structures (e.g. normal faults, thrusts and large-scale tension gashes) appears to be sensitive to variations in mass balance.

Thrust faults, which transport basal till to the surface, typically develop during periods of negative mass balance in the terminal region of the ablation area, when the snout acts as an obstacle.

Normal faults are associated with high glacier surface gradients (relief), both at the lateral margin and in the terminal area.

Sub-vertical crevasses which develop either between two flow units or at the lateral margin of the glacier are interpreted as large scale-tension gashes within shear 
zones. These crevasses are often sigmoidal and therefore indicate contemporaneous growth and shearing.

The angle between crevasses within the northeastern flow unit and the lateral glacier margin varied during the study period. The inclination changed from almost $45^{\circ}$ in 1969 to $28^{\circ}$ in 1997, which could reflect a transition from simple shear to transtension during a period of iceflow deceleration.

\section{ACKNOWLEDGEMENTS}

We acknowledge detailed reviews by B. Goodsell, M. Hambrey and an anonymous reviewer, who helped to clarify ideas and presentation, and encouragement by R. Naruse. We also thank the National Park Institute at the Haus der Natur, Salzburg, and the Grossglockner Hochalpenstrassen AG (GROHAG) for logistical support, especially for permission to establish the high-alpine research station Obernassfeld as our 'base camp', and the GROHAG-Ökofonds for a substantial donation to P.H. BEV, Vienna, (Mr. Kretsek) and the administration of the National Park Hohe Tauern, Tyrol, helped with old maps and aerial photographs. We thank N. Span and M. Kuhn of the Institute of Meteorology and Geophysics, Innsbruck University, for providing the unpublished GPR data from 1997. J. Ploier-Niederschick and D. Fölsche helped to transform all the expressions of 'Austrian English' to British English.

\section{REFERENCES}

Croot, D.G. 1987. Glacio-tectonic structures: a mesoscale model of thin-skinned thrust sheets? J. Struct. Geol., 9(7), 797-808.

Goodsell, B., M.J. Hambrey and N.F. Glasser. 2002. Formation of band ogives and associated structures at Bas Glacier d'Arolla, Valais, Switzerland. J. Glaciol., 48(161), 287-300.

Hambrey, M.J. and N.F. Glasser. 2003. The role of folding and foliation development in the genesis of medial moraines: examples from Svalbard glaciers. J. Geol., 111(4), 471-485.

Hambrey, M.J. and W.J. Lawson. 2000. Structural styles and deformation fields in glaciers: a review. In Maltman, A.J., B. Hubbard and M.J. Hambrey, eds. Deformation of glacial materials. London, Geological Society, 59-83. (Special Publication 176.)

Hambrey, M.J. and A.G. Milnes. 1977. Structural geology of an Alpine glacier (Griesgletscher, Valais, Switzerland). Eclog. Geol. Helv., 70(3), 667-684.

Hambrey, M.J., D. Huddart, M.R. Bennett and N.F. Glasser. 1997. Genesis of "hummocky moraines" by thrusting in glacier ice: evidence from Svalbard and Britain. J. Geol. Soc. London, 153(4), 623-632.

Herbst, P. and F. Neubauer. 2000. The Pasterze glacier, Austria: an analogue of an extensional allochthon. In Maltman, A.J., B. Hubbard and M.J. Hambrey, eds. Deformation of glacial materials. London, Geological Society, 159-168. (Special Publication 176.)
Herbst, P., T. Flandera and F. Neubauer. 2002. A three dimensional model of the Pasterze Glacier, Austria 1887-2001: first results. Z. Gletscherkd. Glazialgeol., 38, 179-184.

Hudleston, P.J. and R.LeB. Hooke. 1980. Cumulative deformation in the Barnes Ice Cap and implications for the development of foliation. Tectonophysics, 66(1-3), 127-146.

Lawson, W. 1996. Structural evolution of Variegated Glacier, Alaska, U.S.A., since 1948. J. Glaciol., 42(141), 261-270.

Lawson, W.J., M.J. Sharp and M.J. Hambrey. 1994. The structural geology of a surge-type glacier. J. Struct. Geol., 16(10), 1447-1462.

Mandl, G. and W. Crans. 1981. Gravitational gliding in deltas. In McClay, K.R. and N.J. Price, eds., Thrust and Nappe tectonics. Geological Society of London, 41-54. (Special Publication 9.)

Manduit, T., G. Guerin, J.-P. Brun and H. Lecanu. 1997. Raft tectonics: the effects of basal slope angle and sedimentation rate on progressive extension. J. Struct. Geol., 19, 1219-1230.

Martel, S.J. 2004. Mechanics of landslide initiation as a shear fracture phenomenon. Marine Geology, 203(3-4), 319-339.

Naylor, M.A., G. Mandl and C.H.K. Sijpesteijn. 1986. Fault geometries in basement-induced wrench faulting under different initial stress states. J. Struct. Geol., 8(7), 737-752.

Paschinger, H. 1969. Die Pasterze in den Jahren 1924 bis 1968. In Büdel, J. and U. Glaser, eds. Neue Forschungen im Umkreis der Glocknergruppe. Innsbruck, 201-218. (Wiss. Alpenvereinshefte 21.)

Patzelt, G. 1970. Die Längenmessungen an den Gletschern der Österreichischen Ostalpen 1890 bis 1969. Z. Gletscherkd. Glazialgeol., 6(1-2), 151-159.

Patzelt, G. 1985. The period of glacier advances in the Alps: 1965 to 1980. Z. Gletscherkd. Glazialgeol., 21, 403-407.

Patzelt, G. 1999. Werden und Vergehen der Gletscher und die nacheiszeitliche Klimaentwicklung in den Alpen. Nova Acta Leopoldina, 81(314), 231-246.

Peacock, D.C.P. and D.J. Sanderson. 1995. Pull-aparts, shear fractures and pressure solution. Tectonophysics, 241(1-2), 1-13.

Ragan, D.M. 1969. Structures at the base of an ice fall. J. Geol., 77(6), 647-667.

Ramsay, J.G. and M.I. Huber. 1987. The techniques of modern structural geology. Volume 2: Folds and fractures. London, Academic Press.

Rouby, D., H. Fossen and P.R. Cobbold. 1996. Extension, displacement, and block rotation in the larger Gullfaks area, northern North Sea: determined from map view restoration. AAPG Bull., 80(6), 875-890.

Schwarzacher, W. and N. Untersteiner. 1953. Zum Problem der Bänderung des Gletschereises. Österr. Akademie der Wissenschaften, mathematisch-naturwissensch., Sitzungsber. Kl. Abt. Ila, 162(1-4), 111-145.

Sharp, M., W. Lawson and R.S. Anderson. 1988. Tectonic processes in a surge-type glacier. J. Struct. Geol., 10(5), 499-515.

Twiss, R.J. and E.M. Moores. 1992. Structural geology. New York, W.H. Freeman and Company.

Wakonigg, H. and G.K. Lieb. 1996. Die Pasterze und ihre Erforschung im Rahmen der Gletschermessungen. In Wissenschaft im Nationalpark Hohe Tauern Kärnten. Grosskirchheim, 99-115. (Kärntner Nationalparkschriften 8.)

Zuo, Z. and J. Oerlemans. 1997. Numerical modelling of the historic front variation and the future behaviour of the Pasterze glacier, Austria. Ann. Glaciol., 24, 234-241. 